\title{
PEMIKIRAN HARALD MOTZKI TENTANG HADIS (TELAAH METODOLOGI PENELITIAN HARALD MOTZKI TERHADAP KITAB AL-MUSANNAF KARYA ABDURRAZZAQ AS-SAN'ANI)
}

\author{
Shohibul Adib \\ (Institut Agama Islam Nahdlatul Ulama Kebumen) \\ e-mail:adib2279@gmail.com
}

\begin{abstract}
Abstrak
Para orientalis awal melihat sanad sebagai masalah yang sangat urgen dalam pembahasan hadis, Joseph Schacht menyatakan bahwa sanad adalah hasil kreasi dari para ulama abad ke $2 \mathrm{H}$. Harald Motzki mencoba meng-counter pandangan seniornya Joseph Schacht dengan mengajukan kitab al-Musannaf karya Abdurrazzaq as-San'ani sebagai bukti bahwa hadis adalah otentik abad pertama Hijriyah. Benarkah pendapat Harald Motzki tersebut? Bagaimana otentisitas hadis dalam pandangan Harald Motzki? Metode dan pendekatan apa yang digunakannya dalam mengkaji kitab al-Musannaf karya Abdurrazzaq as-San'ani? Sebuah permasalahan epistemologis yang akan dibahas dalam paper in. Temuan dalam penelitian ini bahwa Dating yang dilakukan Harald Motzki terhadap kitab Al-Musannaf Karya Abdurrazzaq As-Shan'ani, dengan menggunakan metode isnad cum analisis dan pendekatan traditional-historical menunjukan bukti bahwa materi-materi yang disandarkan Abd ar-Razzaq kepada keempat informan utamanya adalah otentik. Karenanya, kitab tersebut dinilai sebagai dokumen hadis otentik abad pertama Hijriyah, sekaligus sebagai bukti nyata bahwa hukum Islam telah eksis sejak masa itu. Temuan Motzki ini sekaligus menggugurkan teori seniornya G.H.A. Juynboll J. dan projecting backnya Schacht yang menyatakan keberadaan sistem sanad dimulai pada abad ke-2 $\mathrm{H}$.
\end{abstract}

Kata Kunci: Dating, Hadits, Sanad, Harald Motzki 


\section{A. Pendahuluan}

Al-Qur'an dan Hadis dalam tradisi Islam dikenal sebagai dua teks yang fundamental. ${ }^{1}$ Hadis sendiri merupakan teks fundamental kedua atau fundasi (al-asl), tradisi profetik (al-sunnah), sabda-sabda Nabi dalam perannya sebagai pembimbing bagi masyarakat orang-orang yang beriman dan bukan sebagai instrumen kehendak Illahi, penyampaian firman Tuhan. ${ }^{2}$ Hadis yang salah satu fungsinya sebagai penjelas terhadap ayat-ayat al-Qur'an, ${ }^{3}$ sebagai sumber hujjah kedua dalam Islam jelas merupakan sesuatu yang sangat penting. Sebab, di dalamnya terungkap berbagai tradisi yang berkembang pada masa Nabi Muhammad saw.

Tradisi-tradisi yang hidup pada masa kenabian itu merujuk pada diri pribadi Rasulullah saw. yang di dalamnya syarat akan beragam ajaran Islam, karenanya keberlanjutannya terus berjalan dan berkembang hingga sekarang seiring dengan kebutuhan umat manusia. ${ }^{4}$ Adanya keberlanjutan tradisi itulah sehingga umat Islam dalam konteks kekinian dapat memahami, merekam dan melaksanakan tuntunan ajaran Islam sesuai dengan apa yang telah diteladankan Nabi Muhammad saw.

Mengingat pentingnya fungsi hadis, maka kajian-kaijan atas hadis semakin meningkat, sehingga upaya terhadap penjagaan hadis itu sendiri secara historis telah dimulai sejak masa sahabat yang dilakukan secara selektif demi menjaga keotentikan hadis itu sendiri. ${ }^{5}$

Menurut Kamaruddin Amin, wacana mengenai otentisitas, validitas dan reliabilitas metodologi otentifikasi hadis adalah hal yang paling fundamental dalam kajian hadis. Keraguan sebagian sarjana Muslim atas peran hadis sebagai sumber otoritas kedua setelah al-Qur'an, tidak sepenuhnya berkaitan dengan

\footnotetext{
1 Abu Zayd adalah tokoh yang mempopulerkan konsep al-Qur'an dan hadis sebagai teks. Lihat Nasr Hamid Abu Zayd, Mafhum al-Nash: Dirasah fi Ulum al-Qur'an (Beirut: al-Markaz al-Tsaqafi al-Arabi, 2000). Lihat juga karyanya yang lain Rethingking the Qur'an: Toward a Humanistic Hermeneutics (Amsterdam: Humanistic University Press, 2004), hlm. 9-12.

2 M.Arkaoun, Rethingking Islam, terj. Yudian W. Yasmin dan Lathiful Khuluq (Yogyakarta: Pustaka Pelajar, 1996), hlm. 73.

3 (Qs: an-Nahl (16): 44).

4 M. Alfatih Suryadilaga, "Model-model Living Hadis", dalam Sahiron Syamsuddin (ed.), Metodologi Penelitian Living Qur'an dan Hadis (Yogyakarta: Th-Perss dan TERAS, 2007), hlm. 105.

5 Muhammad 'Ajjaj al-Khatib, Al-Sunnah Qabl al-Tadwin (Beirut: Dar al-Fikr, 1981), hlm. 92-93.
} 
resistensi mereka atas otoritas sunnah, tetapi lebih pada keraguan mereka atas keakuratan metodologi yang digunakan dalam menentukan originalitas hadis. Apabila metodologi otentifikasi yang digunakan bermasalah, maka semua hasil yang dicapai dari metode tersebut tidak steril dari kemungkinan-kemungkinan verifikasi ulang, kritik sejarah bahkan hasil tersebut bisa menjadi collapse. ${ }^{6}$

Keraguan juga datang dari kalangan orientalis mengenai otentisitas hadis. Epistemologi kaum orientalis dengan ciri skeptis atau keragu-raguan (kesangsian)-nya mencoba menanyakan ulang apakah sesungguhnya hadis itu? Benarkah hadis itu adalah ucapan verbal nabi, tingkah laku nabi atau persepsi masyarakat Islam tentang nabi? Apakah buku hadis yang kita warisi dari abad ketiga seperti Sahih Bukhari dan Muslim, merupakan refleksi sunnah nabi? Mazhab skeptis ini diwakili oleh Joseph Schacht (Austria) dan Ignaz Goldziher (Honggaria). Meskipun demikian, pada dekade terahir mazhab skeptis yang telah mapan di Barat tidak lagi menjadi satunya-satunya trend yang mendominasi diskursus studi Islam di Barat. Mazhab non-skeptis yang dikomandani oleh sejumlah Orientalis sekaliber Harald Motzki, Fuec, Scheoler, dan lain-lain turut meramaikan diskursus masa awal Islam.

Para orientalis awal melihat sanad sebagai masalah yang sangat urgen dalam pembahasan hadis, Joseph Schacht menyatakan bahwa sanad adalah hasil kreasi dari para ulama abad ke $2 \mathrm{H}$. Harald Motzki mencoba mengcounter pandangan seniornya Joseph Schacht dengan mengajukan kitab alMusannaf karya Abdurrazzaq as-San'ani sebagai bukti bahwa hadis adalah otentik abad pertama Hijriyah. Benarkah pendapat Harald Motzki tersebut? Bagaimana otentisitas hadis dalam pandangan Harald Motzki? Metode dan pendekatan apa yang digunakannya dalam mengkaji kitab al-Musannaf karya Abdurrazzaq as-San'ani? Sebuah permasalahan epistemologis yang akan dibahas dalam paper ini. ${ }^{7}$

\footnotetext{
Lihat, Kamaruddin Amin, The Reliability of Hadith Transmission, A Reexamination of Hadith Critical Methods, Bonn 2005).

7 Epistemologi secara garis besar memiliki tiga permasalahan pokok, yakni masalah sumber, watak dan validitas. J. Sudarminta, Epistemologi Dasar: Pengantar Filsafat Pengetahuan (Yogyakarta: Kanisius, 2002), hlm. 18-21. Lihat juga Harold HAL. Titus dkk., Persoalan-persoalan Filsafat, terj. Rasyidi (Jakarta: Bulan Bintang, 1984), hlm. 20-21. lihat juga D.W. Hamlyn, "History of Epistemologi”, dalam Paul Edwards, The Encyclopedia of Philosophy, Vol. III, 1967, hlm. 94. Sebagai cabang dari filsafat yang menyelidiki tentang keaslian pengertian, struktur, metode dan validitas ilmu pengetahuan, epistemologi dalam konteks paper ini akan membahas latar belakang pemikiran,
} 


\section{B. Latarbelakang Penelitian Harald Motzki.}

Misteri adalah kata dan natijah sementara dari penyusun terkait dengan masalah biografi Harald Motzki, setelah melaui "kristalisasi pemikiran" dengan sarana teknologi tradisional berupa jurnal dan majalah hingga teknologi modern berupa internet, penyusun belum menemukan data lengkap mengenai biografi Harald Motzki. Sejauh yang penyusun ketahui hingga saat ini, Harald Motzki adalah seorang orientalis yang menjadi Guru Besar di Universitas Nijmegen, Belanda. ${ }^{8}$

Pada hakekatnya setiap orang adalah produk dari lingkungannya, dan terpengaruh oleh sistem-sistem eksternal, yang ada dalam kondisi sosial, politik, dan budaya sekelilingnya. Oleh karena itu, sebelum meneliti sebuah objek, terlebih dahulu harus memiliki pandangan yang holistik, menyeluruh dan seksama tentang objek tersebut. ${ }^{9}$ Dalam hal ini, biografi Harald Motzki sangat penting diketahui guna melihat latar belakang kehidupanya. Karena biografinya belum ditemukan, maka penyusun menganalisa latarbelakang pemikirannya dengan melihat konteks sejarah perkembangan pemikiran orientalis secara umum. Berawal dari teori hermeneutika ini lah, sebagai seorang orientalis, Harald Motzki jelas tidak bisa lepas dari sistem-sistem eksternal yang ada disekitarnya, yakni pengaruh dari pemikiran kaum orientalis sebelumnya.

Data sejarah menunjukkan, pemikiran orientalis awal melihat keberadaan sanad $^{10}$ sebagai masalah yang sangat urgen dalam pembahasan hadis. Sebab,

sumber dan metode yang digunakan Harald Motzki dalam mengkaji kitab al-Musanaf karya Abdurrazzaq as-San'ani.

8 Syamsuddin 'Arif, "Gugatan Orientalis terhadap Hadis dan Gaungnya di Dunia Islam", dalam Jurnal al-Insan, Jakarta, No. 2, Vol. I, 2005, hlm. 15. Lihat juga Kamaruddin Amin, ”Problematika Ulumul Hadis Sebuah Upaya Pencarian Metodologi Alternatif", dalam.www.ditpertais.net/ annualconference/ancon06/makalah/Makalah\%20Komaruddin..doc. Di antara karya Motzki adalah The Origins of Islamic Jurisprudence: Meccan Fiqh before the Classical Schools (Leiden: Boston Koln, 2002), "The Musannaf of ar-Razaq as-San'ani a Source of Authentic Ahadith of the First Century", dalam Journal of Near Easern Studies, The Propeht and Car on Dating Malik's Muwatta and Legal Tradition, Biography of Muhammad (1998). The Author and his Work in Islamic Literature of the First Centuries: The Case of 'abd ar-Razaq's Musannaf, Jerusalem Studies in Arabic and Islam (ForthComing). Lihat Harald Motzki, The Origins of Islamic Jurisprudence: Meccan Fiqh before the Classical Schools (Leiden: Boston Koln, 2002), hlm. 307.

9 E. Sumaryono, Hermeneutika, Sebuah Metode Filsafat (Yogyakarta: Kanisius, 1993), hlm. 40.

10 Sanad secara etimologi sesuatu yang diangkat dari bumi, atau tempat bertumpunya sesuatu, jalan (al-thariq), arah (al-wajh). Secara terminologi jalan matn, yakni serangkaian periwayat yang 
masalah sanad berkaitan langsung dengan otentisitas hadis. ${ }^{11}$ Kapan awal mula pemakaian sistem sanad digunakan? Adalah permasalahan kontroversial yang sering diperdebatkan di kalangan kaum orientalis. Menurut Caetani dan Sprenger pemakaian sanad baru dimulai pada masa antara Urwah (w. $94 \mathrm{H}$ ) dan Ibn Ishaq (w. $151 \mathrm{H}$ ) sehingga sebagian besar sanad yang terdapat dalam kiab hadis adalah buatan ahli hadis abad ke-2 atau bahkan pada abad ke-3.

Pendapat berbeda datang dari Horovitz, menurutnya pemakaian sanad dalam periwayatan sudah dimulai sejak sepertiga terakhir dari abad pertama Hijriyah, sementara menurut J. Robson dimulai pada pertengahan abad pertama. $^{12}$

Secara umum, G. H. A. Juynboll dalam hal ini memetakan tiga pendapat yang menonjol terkait dengan masalah awal mula pemakaian sanad dalam studi hadis. Pertama, pendapat umum sarjana muslim yakni sejak perang sipil I di mana Usman bin affan terbunuh Tahun 35 H. Kedua, J. Schacht, sejak perang sipil ke-3, di mana Khalifah Umayah Walid bin Yazid terbunuh Tahun 126 H. Ketiga, pendapatnya G. H. A. Juynboll sendiri, yakni sejak perang sipil ke-2 di mana Abdullah bin Zubair memproklamirkan pemerintahan tandingan di Makkah Tahun $63 \mathrm{H} .^{13}$

Dari pemetaan G.H.A. Juynboll tersebut, tampak pendapat J. Schacht yang menyatakan keberadaan sistem sanad dimulai pada abad ke-2 $\mathrm{H}$, atau

memindahkan (meriwayatkan) matn dari sumber awalnya. Muhammad 'Ajjaj al-Khatib, Ushul al-Hadis; 'Ulumuhu wa Mushthalahuhu (Beirut: Dar al-'Ilmu li al-Malayin, 1977), hlm, 32. Muhammad Mustafa Azami, Studies in Hadith Methodology and Literatur, edisi Indonesia terj. A. yamin Metodologi Kritik Hadis, terj. A. Yamin (Jakarta: Pustaka Hidayah, 1992), hlm. 61.

11 Hal yang sama juga terjadi dalam tradisi intelektual Islam. Muhammad ibn Sirin menyatakan "sesungguhnya pengetahuan hadis adalah agama, maka perhatikanlah dari siapa kamu mengambil agama itu".. Hal senada diungkapkan oleh Abdullah bin Mubarak dengan menambahkan jika sanad tidak ada, maka siapa saja akan bebas menyatakan apa yang dikehendakinya. Selain itu, salah satu sebab pentingnya penelitian sanad adalah adanya fenomena seperti pemalsuan hadis. Muslim bin al-Hajjaj, Shahih Muslim bi Syarh al-Nawawi (Beirut: Dar al-Kutub al-Ilmiah, 2003), I: 78. Lihat juga Syuhudi Ismail, Kaedah Kesahihan Sanad Hadis: Telaah Kritis dan Tinjauan dengan Pendekatan Ilmu Sejarah (Jakarta: Bulan Bintang, 1988), hlm. 75-104.

12 Muhammad Mustafa Azami, Hadis Nabawi dan Sejarah Kodifikasinya, terj. Ali Mustafa Yaqub (Jakarta: Pustaka Firdaus, 2004), hlm. 531-534.

13 G.H.A. Juynboll, "Some Notes on Islam's First Fuqaha' Distilled from Early Hadith Literature" dalam G.H.A. Juynboll, Studies on the Origins and Use of Islamic Hadith (Great Britain: Variorum, 1996), hlm. 290-291. 
paling awal akhir abad pertama. ${ }^{14}$ Sumber epistemologi yang digunakan J. Schacht adalah kitab Muwata karya Imam Malik, al-Muwata-nya al-Syaibani, dan al-Umm karya Imam Syafi'i. Dari kitab-kitab fiqh ini lah J. Schacht meneliti kapan awal mula penggunaan sanad hadis. Schacht dengan metode projecting back ${ }^{15}$ sampai pada kesimpulan bahwa hukum Islam belum eksis pada masa awal Islam. Sebab, hadis (yang dimaksud adalah hadis ahkam) tidak digunakan sebagai argumen dalam diskusi hukum Islam. ${ }^{16}$ Hukum Islam sendiri baru diterapkan pada masa Bani Umayyah. ${ }^{17}$ Oleh karena itu, keotentikan hadis layak diragukan, sebuah kesimpulan yang kemudian dipertegas oleh Juynboll. ${ }^{18}$

Diskursus keotentikan hadis di kalangan orientalis yang berujung pada kontroversi eksistensi hukum Islam di atas adalah tradisi yang melatarbelakangi pemikiran Harald Motzki. Hal ini tampak ketika Motzki mencoba mengcounter pendapat J. Schacht dengan asumsi bahwa hukum Islam telah eksis sejak abad pertama Hijriyah sehingga jurisprudensi Islam yang didasarkan atas al-Qur'an dan hadis adalah sumber yang otentik. Guna membuktikan kesahihan asumsinya ini, Harald Motzki melakukan penelitian kitab al-Mus\}annaf Karya Abdurrazzaq as-Shan'ani.

\section{Kajian Harald Motzki atas Kitab al-Musannaf Karya Abdurrazzaq as-San'ani.}

\section{Kitab al-Musannaf Karya Abdurrazzaq: Sebagai Objek Penelitian Harald Motzki.}

Dari penelusuran penyusun dapat diketahui bahwa Al-Hafiz| al-Kabir Abi Bakar 'Abd al-Razaq Ibn Hammam as-San'ani adalah nama lengkap dari

14 Muhammad Mustafa Azami, Menguji Keaslian Hadis-hadis Hukum (Jakarta: Pustaka Firdaus, 2004), hlm. 232.

15 Ahmad Minhaji, Kontroversi Pembentukan Hukum Islam; Kontribusi Joseph Schacht (Yogyakarta: UII Press, 2001), hlm. 22.

16 Teori yang diajukan adalah argumen e silentio, Joseph Schacht, The Origins of Muhammadan Jurisprudence (Oxford: Ciarenoon Press, 1950), hlm. 40.

17 Ali Mustafa Ya’qub, Kritik Hadis (Jakarta: Pustaka Firdaus, 2000), hlm. 20.

18 Joseph Schacht, An Introduction to Islamic Law (Oxford: Clarendon Press, 1990), hlm. 11. G.H.A. Juynboll, Muslim Tradition; Studies in Chronology Provenance and Authorship of Early Hadith (Cambridge: Cambridge University, 1983), hlm. 98. 
'Abd al-Razaq as-San'ani. ${ }^{19}$ 'Abd al-Razaq yang juga menulis kitab tafsir li alAbd al-Razaq lahir pada $126 \mathrm{H}$ di daerah San'an, ${ }^{20}$ ia pernah berkelana dalam rangka mengumpulkan hadis Nabi sambil berdagang di mulai dari kawasan Hijaz, Syam, hingga kawasan Baghdad, Irak. ${ }^{21}$

Salah satu dari guru 'Abd al-Razaq sebagaimana disebutkan Ibn Hajar al-Asqalani adalah: ${ }^{22}$

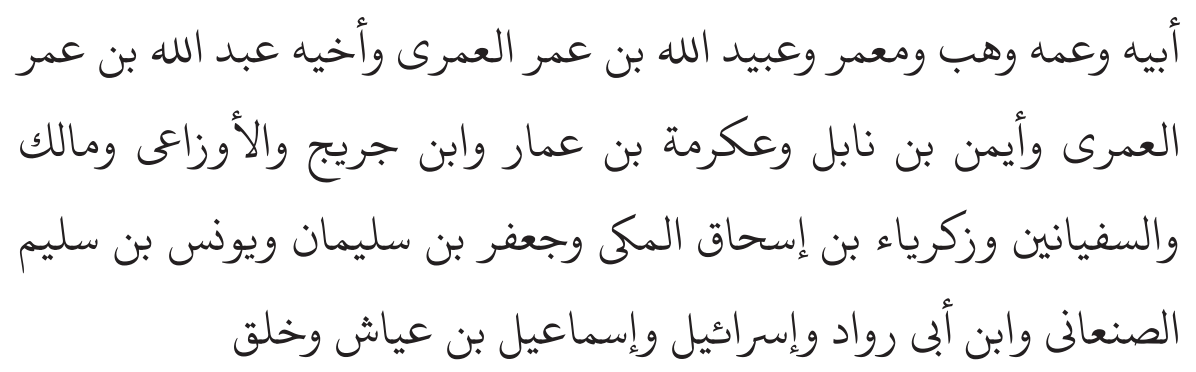

Adapun murid-murid dari 'Abd al-Razaq antara lain:23

19 Dalam penisbatannya ditemukan al-Yamani dan al-Himyari yang terakhir diambil dari fakta sejarah bahwa ia adalah Maula Himyar. Lahir pada 126 H/ 744 M, besar dan belajar di daerah Yaman. Ia pernah melakukan perjalanan ke Syiria yang melewati daerah Makah dan Madinah dengan menemui beberapa ulama di daerah tersebut. Guru utamanya adalah Ma’mar ibn Rasyid dari Basrah yang mukim di Yaman. Ia belajar dengan gurunya tersebut selama 7,8 atau 9 tahun. Belajar dari Sufyan as-Sauri di Yaman pada 149, dan pada $150 \mathrm{H}$ belajar kepada Sufyan bin 'Uyanah. Ia Meninggal pada usia 85 tahun pertengahan bulan Syawal 211 H/ 827 M. Harald Motzki, The Origins of Islamic Jurisprudence: Meccan Figh before the Classical Schools (Leiden: Boston Koln, 2002), hlm. 63.

20 Abu 'Abdullah Muhammad bin Ahmad Az-Zahaby, Mizan al-I'tidal fi Naqd al-Rijal (T.tp.: Isa alBabi al-Halaby, 1963), Juz II hlm. 609. Abu 'Abdullah Muhammad bin Ahmad Az|-Zahaby dalam Siyar a'lam an-Nubula' memberikan informasi seputar kehidupan dan atau riwayat hidup 'Abd alRazaq yang dapat diperoleh dalam beberapa karya, yaitu:

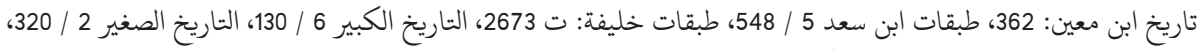

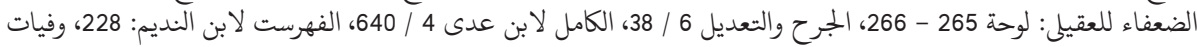

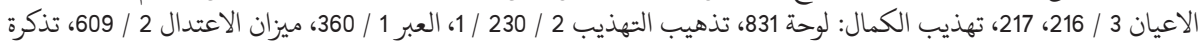

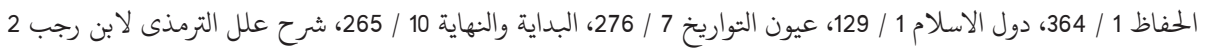

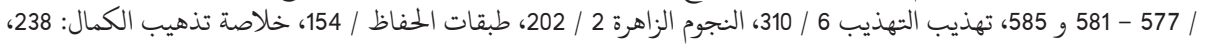
شذرات الذهب 2 / 27

Lihat Abu 'Abdullah Muhammad bin Ahmad Az-Zahaby, Siyar a'lam an-Nubula' dalam CD Maktabah al-Syamilah versi III atau al-Isdar al-Salis, Juz IX hlm. 563.

22 Ibn Hajar al-Asqalani, Tahzib al-Tahzib, CD Maktabah al-Syamilah versi III atau al-Isdar al-Salis. Juz VI 278 No. 611

نَفَس المراجع 


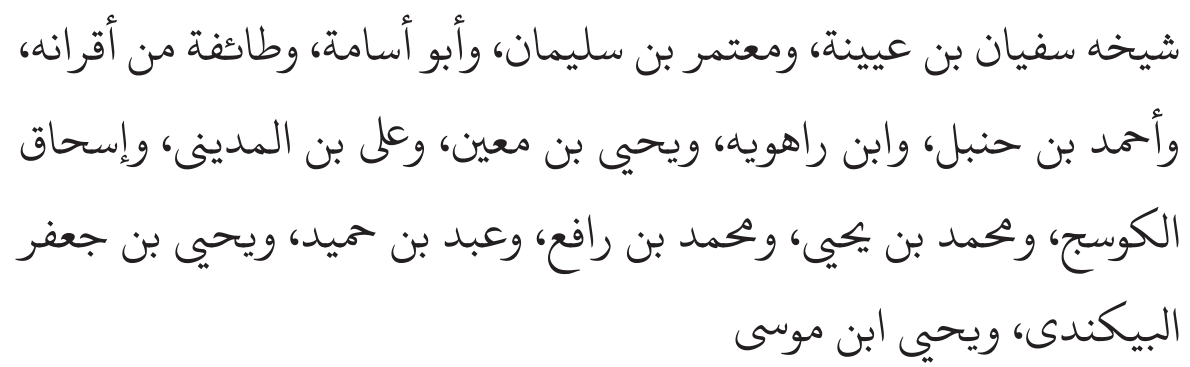

Sejarah mencatat bahwa 'Abd al-Razaq meninggal di daerah Yaman pada pertengahan bulan Syawal Tahun $211 \mathrm{H} .{ }^{24}$ Banyak ulama yang memberikan penilaian positif terhadap pribadi 'Abd al-Razaq, mereka antara lain:

a. Menurut Ibn Hajar dia adalah 26 ثقة حافظ 25 الأعمة الأعلام الحفاظ

b. Menurut ad-Daruqutni dia adalah ثقة

c. Menurut al-Bukhari: ما حدث عنه عبد الرزاق من كتابه فهو أصح فقة

d. Menurut Abu Zur'ah ad-Dimsyaqy dari Ahmad bin Hanbal bahwa 'Abd al-Razaq adalah يحفظ حديث bahkan terkadang dikatakan ثقة.27

e. Menurut Siyar bin Hatim sebagai berikut:

$$
\begin{aligned}
& \text { وأرجو أنه لا بأس به، والذى ذكر فيه من التشيع والروايات التى رواها } \\
& \text { التى يستدل بها على أنه شيعى، فقد روى أيضا فى فضل الشيخين، } \\
& \text { وأحاديثه ليست بالمنكرة، وما كان فيه منكر، فلعل البلاء فيه من } \\
& \text { الراوى عنه، وهو عندى ممن يجب أن يقل حديثه }
\end{aligned}
$$

f. Menurut Abu Ahmad, 'Abd al-Razaq banyak meriwayatkan hadis ia mengatakan

24 Muhammad Ibn Sa'ad, at-Tabaqat al-Kubra (Leiden: E.J.Brill, 1322 H.), Juz V hlm. 548. Adam alKharasani, Mausu'ah A'lam, dalam Maktabah al-Syamilah versi III atau al-Is\}dar al-Salis Juz I, hlm. 286.

25 Lihat Ibn Hajar al-Asqalani, Lisan al-Mizan Bab من اسمه عبد الرحيم وعبد الرزاق dalam CD Maktabah al-Syamilah versi III atau al-Isdar al-Salis, Juz II hlm. 221.

26 Ibn Hajar al-Asqalani, Taqrib al-Tahzib, dalam CD Maktabah al-Syamilah versi III atau al-Isdar al-Salis, Juz I, hlm. 599.

27 Abu 'Abdullah Muhammad bin Ahmad Az-Zahaby, Mizan al-I'tidal 


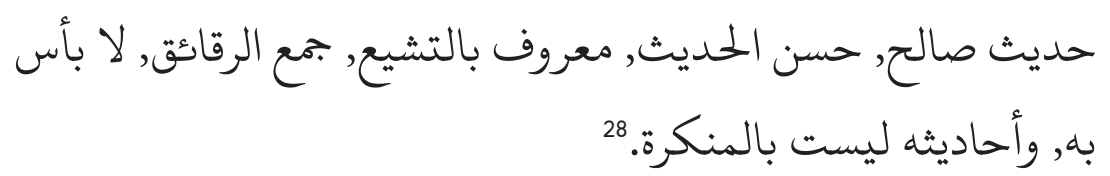

g. Menurut Ya'qub bin Syaibah, 'Ali bin al-Madiniy, Hisyam bin Yusuf:

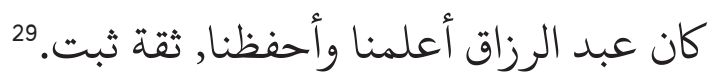

Dari biografi dan komentar beberapa ulama di atas, maka dapat disimpulkan: pertama, 'Abd al-Razaq adalah seorang periwayat yang adil ${ }^{30}$ dan dhabit. ${ }^{31}$ Adapun tingkatan adil-nya 'Abd al-Razaq berdasarkan kriteria yang dibangun 'Ajjāj al-Khātib sangat bervariasi, yakni masuk dalam tingkatan ta'dil ketiga, kelima, dan keenam. Keadilan 'Abd al-Razaq pada tingkatan ketiga tampak dari komentarnya Ibn Hajar, Abu Zur'ah ad-Dimsyaqy, Ya'qub bin Syaibah, 'Ali bin al-Madiniy, dan Hisyam bin Yusuf. Komentar Abu Ahmad masuk dalam kriteria tingkatan ta'dil kelima. Sementara itu, tingkatan ta'dil keenam tampak dari komentar yang diberikan oleh Siyar bin Hatim, dan Abu Ahmad. ${ }^{32}$

28 Yusuf bin az-Zaki al-Mizzi, Tahzib al-Kamal dalam CD Maktabah al-Syamilah versi III atau al-Isdar al-Salis, Juz IV, hlm. 47.

29 نَفَس المراجع

30 Adil tidak hanya bermakna pertengahan, lurus, atau condong kepada kebenaran (Ibn Manzur., Lisān al-Arab (Mesir: Dār al-Mishriyyah li al-Tảlif wa al-Tarjamah, 1868), XIII: 456). melainkan lebih, yakni adil dalam pengertian studi ilmu hadis. Para ulama berbeda pendapat mengenai kriteria keadilan periwayat (Muhammad Hakim al-Naisabury, Márifat Ulum al-Hadis; Kairo: Maktabah alMutanaby, t.t, hlm. 53; dalam hal ini Syuhudi Ismail merangkum beragam pendapat ulama menjadi empat hal, yakni: Islam, Mukalaf, melaksanakan ketentuan agama, dan memelihara muru’ah. Ismail. Syuhudi, Kaedah Kesahihan Sanad Hadis: Telaah Kritis dan Tinjauan dengan Pendekatan Ilmu Sejarah (Jakarta: Bulan Bintang, 1988), hlm. 113-118. Syuhudi Ismail, Metodologi penelitian Hadis Nabi (Jakarta: Bulan Bintang, 1992), hlm. 67.

31 Dhabit berarti yang kuat, yang tepat, dan yang hafal dengan sempurna Lihat Al-Fayyumi, Al-Misbah al-Munir fi Gharib al-Syarh al-Kabir li ar-Rafi'i (Beirut: Dar al-Kutub al-'Ilmiyyah), II: 420-421. Dalam studi hadis istilah dhabit lebih dikaitkan dengan kapasitas intelektual periwayat. Lihat Syuhudi Ismail, Metodologi, hlm. 70.

32 Ta'dil tingkatan tiga adalah kata-kata yang mengukuhkan kualitas siqah dengan salah satu sifat di antara sekian sifat adil dan siqah, baik dengan kata yang sama atau yang searti. Tingkat lima adalah kata-kata yang menunjukkan sifat adil, tetapi menggunakan kata yang tidak menyiratkan kedhabitan, sedangkan tingkat enam adalah kata-kata yang sedikit menyiratkan makna tarjih. Lihat 'Ajjāj al-Khātib, Muhammad, Usūl al-Hadis; 'Ulūmuhu wa Mustalahuhu (Beirut: Dār al-'Ilm li alMalayin, 1977), hlm. 231. 
Kedua, dilihat dari tangal lahir dan kematian, maka 'Abd al-Razaq yang lahir pada $126 \mathrm{H}$ dan meninggal pada Tahun $211 \mathrm{H}$ masih tergolong sebagai seorang tabi'in. Hal ini berdasarkan pendapat mayoritas ulama yang menyatakan bahwa akhir masa tabi'in adalah tahun $150 \mathrm{H}$ dan akhir masa tabi' al-tabi' in adalah tahun $220 \mathrm{H}^{33}$

Sejarah menunjukkan bahwa metode penyusunan kitab-kitab hadis sangat beragam atau tidak seragam. Para mukharij memiliki metode-metode sendiri-sendiri dalam penyusunan sistematika dan penempatan topik masalah. Hal ini dinilai sebagai sesuatu yang wajar oleh Syuhudi Ismail. Sebab, kegiatan penulisan hadis yang dilakukan para ulama terdahulu lebih terkonsentrasikan pada penghimpunan hadis dan tidak pada metode penyusunannya. ${ }^{34}$

Adapun kitab al-Musannaf karya 'Abd al-Razaq jika dilihat dari namanya, maka kitab ini menggunakan metode al-Musannaf. Kata al-Musannaf meskipun secara bahasa bermakna sesuatu yang disusun, namun secara terminologis kata al-Musannafadalah نَفَس atau the same thing (sama) dengan istilah muwata' yakni sebuah metode pembukuan hadis berdasarkan klasifikasi hukum Islam atau (ابواب فقهيه) bab-bab fiqh di mana di dalamnya mencakup hadis mauquf, hadis maqtu' yang disatukan dengan hadis marfu, ${ }^{35}$ yang oleh ulama mutaqaddimin disebut dengan al-Asnaf. ${ }^{36}$

Menurut Goldziher istilah al-Musannaf di definisikan sebagai koleksi di mana para perawi yang dirujuk oleh isnad-isnad itu tidak menentukan urutan perkataan dan isisnya. Namun, hubungan isi dan rujukan perkataanya pada masalah yang sama. Materi yang menjadi pokok bahasan hadis-hadis bukan hanya umum, yang terkait dengan ritual, melainkan juga yang terkait dengan masalah biografis, historis, dan etis. ${ }^{37} \mathrm{Di}$ antara kitab hadis yang termasuk dalam kategori al-Musannaf ini adalah al-Jawami, as-Sunan, al-Musannafat, al-Mustadrakat, al-Mustakhrajat. ${ }^{38}$

\footnotetext{
33 'Ajjāj al-Khātib, Muhammad, Usūl al-Hadis, hlm. 352.

34 Syuhudi Ismail, Metodologi penelitian, hlm. 19.

35 'Ajjāj al-Khātib, Al-Sunnah Qabl al-Tadwin (kairo: Maktabah Wahbah, 1963), hlm. 134.

36 Lihat Nuruddin al-Itr, Ulumul Hadis, terj. Endang Soetari dan Mujio (Bandung: Rosdakarya, 1992), hlm. 181.

37 Ignaz Goldziher, Muslim Studies (London: t.tp., 1967), II: 214.

38 Muhammad Mustafa Azami, Studies in Hadith Methodology and Literatur, edisi Indonesia terj. A. yamin Metodologi Kritik Hadis, terj. A. Yamin (Jakarta: Pustaka Hidayah, 1992), hlm. 108.
} 
Sementara itu, dilihat dari setting sejarahnya, maka koleksi kitab hadis yang menggunakan metode al-Musannaf muncul pada pertengahan abad pertama dan tersebar luas pada pertengahan abad ke-2 H. Di antara penulis yang menyusun kitab hadis dengan kompilasi seperti karya 'Abd al-Razaq adalah karya Abu Bakr bin Syaibah (w. 235 H), Abu Rabi' Sulaiman bin Abi Dawud az-Zahiri (w. $234 \mathrm{H}) .{ }^{39}$ Terdapat juga Musannaf Hammad bin Salamah (w. $181 \mathrm{H}$ ), Musannaf yang dinisbahkan pada Waki' al-Jarrah (w. $197 \mathrm{H}) .{ }^{40}$

Kitab al-Musannaf karya 'Abd al-Razaq ini diterbitkan oleh Majelis al'Ilmi, Beirut pada Tahun 1983/ $1403 \mathrm{H}$ dalam 11 (sebelas) jilid dan di tahqiq dan disajikan kembali oleh Habib ar-Rahman al-Azami. ${ }^{41}$ Pembacan atas kitab al-Musannaf editan Habib ar-Rahman tersebut lebih dipermudah dengan adanya satu kitab katalog yang disusun oleh Ma'mar bin Rasyid al-Azdiy. Kitab yang sangat membantu ini terdiri dari tiga katalog, yakni: pertama: katalog untuk lafaz hadis. Kedua, katalog untuk istilah-istilah fiqhiyyah, dan ketiga, berisi tentang indeks atau biografi. ${ }^{42}$

Sebagaimana yang penyusun jelaskan di atas, kitab al-Musannaf karya Abd ar-Razzaq ini dijadikan sebagai objek penelitian bagi Harald Motzki guna membuktikan asumsinya bahwa hukum Islam telah eksis sejak abad pertama Hijriyah.

\section{Metode dan Pendekatan Harald Motzki.}

Harald Motzki tidak secara eksplisit menyebutkan langkah-langkah penelitian yang sistematis ketika melakukan penelitian kitab Musannaf Abd ar-Razaq. Meskipun demikian, dari data yang ada, penyusun mencoba menggambarkan metode, pendekatan, dan langkah-langkah sistematis yang ditempuh Harald Motzki sebagai berikut:

Pertama, sebagai langkah awal, Motzki melakkan dating yakni menentukan asal-muasal dan umur terhadap sumber sejarah yang merupakan salah satu substansi penelitian sejarah. Jika dating yang dilakukan oleh seorang

39 Syaukat Jamilah, "Pengklasifikasian Literatur Hadis", dalam Al-Hikmah, No. 13 April-Juni 1994, hlm. 24-26.

40 Muhammad bin Ja'far al-Kattani, Ar-Risalah al-Mustafat (Beirut: Dar al-Ilmi, 1322), hlm. 31.

41 Penyusun hingga saat ini belum menemukan biografi Habib ar-Rahman al-'Azami.

42 Ma’mar bin Rasyid al-Azdiy, Faharis al-Musannaf 'Abd al-Razaq (Beirut: al-Maktab al-Islamiy, t.t.), hlm. 1. 
peneliti terhadap sebuah sumber sejarah terbukti tidak valid dikemudian hari, maka seluruh premis teori dan kesimpulan yang dibangun atas sumber sejarah tersebut menjadi colleps (roboh). Teori inilah yang menjadi epistemologi Motzki dalam merekonstruksi sejarah awal Islam dalam karyanya The Origins of Islamic Jurisprudence. ${ }^{43}$

Kedua, Motzki tidak melakukan penelitian secara keseluruhan hadis-hadis yang terdapat dalam sumber primernya Mus\}annaf Abd ar-Razaq. Namun, ia menggunakan metode sampling, yakni mengambil beberapa bagian yang diangap telah mewakili populasi dari yang diteliti. Tujuan dari penentuan sampel ini adalah untuk menghindari kekeliruan generalisasi dari sampel ke populasi. ${ }^{44}$ Motzki dalam hal ini meneliti 3810 hadis dari keseluruhan kitab Musannaf Abd ar-Razzaq yang berjumlah 21033 hadis. Dengan demikian ia meneliti sekitar $21 \%$ hadis. ${ }^{45}$

Ketiga, setelah data terkumpul, maka Motzki kemudian menganalisis sanad dan matn dengan menggunakan metode isnad cum analisis dengan pendekatan traditional-historical yakni sebuah metode yang cara kerjanya menark sumber-sumber awal dari kompilasi yang ada, yang tidak terpelihara sebagai karya-karya terpisah, dan memfokuskan diri pada materi-materi para perawi tertentu ketimbang pada hadis-hadis yang terkumpul pada topik tertentu. Jadi, traditional-historical dijadikan sebagai alat untuk menganalisa dan menguji materi-materi dari perawi. ${ }^{46}$ Oleh karena itu, penelitian struktur periwayatan yang dilakukannya memberikan kesimpulan bahwa materimateri yang diletakkan atas nama empat tokoh sebagai sumber utamanya adalah sumber yang otentik, bukan penisbatan fiktif yang direkayasa. ${ }^{47}$

Keempat, terkait dengan materi periwayatan (matn) hadis, Motzki mengajukan teori external criteria dan formal criteria of authenticity sebagai alat analisa periwayatan. ${ }^{48}$

43 Kamaruddin Amin, "Book Review The Origins of Islamic Jurisprudence Meccan Fiqh before the Classical School”, dalam Al-Jamiah: Journal of Islamic Studies (Yogyakarta: UIN Sunan Kalijaga Yogyakarta, 2003, No. 1, Vol. 41), hlm. 2.

44 Metode sampling ini dalam penelitian kontemporer, secara akademik dapat dipertanggungjawabkan keabsahannya. Lihat Sumardi Suryabrata, Metodologi Penelitian (Jakarta: Rajagrafindo Persada, t.t), hlm. 81-82.

45 Harald Motzki, The Origins of Islamic, hlm. 58.

46 Harald Motzki, "The Musannaf of ar-Razaq as-San'ani a Source of Authentic Ahadith of the First Century”, dalam Journal of Near Easern Studies, Vol. 50. No. 1, hlm. 1-21.

47 Ibid.

48 Ibid., hlm. 77-94. 
Kelima, penyusun sebut sebagai tahap aplikasi. Berangkat dari metodemetode di atas, Motzki kemudian mengklasifikasikan terhadap riwayat yang terdapat dalam kitab Mus\}annaf.

Motzki dalam penelitiannya menemukan tiga sumber dominan yang sering dirujuk oleh Abd ar-Razaq, yang memberikan kontribusi ribuan hadis, mereka adalah Ma'mar, Ibn Jurayj, dan Sufyan as-Sauri. ${ }^{49}$ Guna membuktikan masalah ini, Motzki meneliti empat tokoh sebagai sumber otoritas utama dari Abd ar-Razzaq, yakni Ma’mar di mana ar-Razzaq meriwayatkan materinya sekitar 32\%, Ibnu Jurayj 29\%, as-Sauri 22\%, dan Ibn Uyainah 4\%. Sisanya adalah sekitar $13 \%$ yang berasal dari $90 \%$ tokoh yang berbeda dan kurang dari $1 \%$ tokoh yang berasal dari abad ke-2 $\mathrm{H}$ seperti Abu Hanifah 0,7\%, dan Imam Malik sebesar $0,6 \% .^{50}$

Dari pemilahan tersebut, menurut Motzki setiap koleksi memiliki karakteristik tersendiri, dan hampir mustahil seorang pemalsu dapat memberikan sumber yang begitu bervariasi, apalagi jika penelitian ini difokuskan pada asal perawi dan karakter teks yang diriwayatkan. Guna mendukung pandangannya bahwa ar-Razzaq bukan seorang pemalsu, maka Motzki mengutip biografinya khususnya terkait dengan guru-gurunya arRazzaq. ${ }^{51}$ Lebih lanjut, Motzki mengklasifikasikan riwayat yang terdapat dalam Musannaf Abd ar-Razzaq sebagai berikut:

a. Ma’mar (w. $153 \mathrm{H}$ ) 32\% dengan konfigurasi materi yang berasal darinya adalah Ibn Syihab az-Zuhri 28\%, Qatadah bin Diama 25\%, Ayyub bin Abi Tamima 11\%, orang tanpa nama (anynamous) 6\%, Ibn Tawus 5\%, Ma’mar 1\%, 77 orang 24\% jumlah total 100\%.

b. Ibn Jurayj (w. $150 \mathrm{H}$ ) 29\% dengan konfigurasi materi yang berasal darinya adalah 'Ata' ibn Rabah 39\%, orang tanpa nama (anynamous)

49 Ketiga tokoh tersebut merupakan guru dari 'Abd al-Razaq. Lihat Ibn Hajar al-Asqalani, Tahzib alTahzib, CD Maktabah al-Syamilah versi III atau al-Isdar al-Salis. Juz VI 278 No. 611.

50 Harald Motzki, The Origins of Islamic, hlm. 58.

51 Lihat catatan kaki No. 21. Jangankan ar-Razzaq yang telah jelas identitasnya, menurut al-Sakhawi label "jahalah" bagi perawi pun akan hilang manakala terdapat dua periwayat yang meriwayatkan hadis dari perawi tersebut. Al-Sakhawi, Fath\} al-Mugis, Syarh al-Fiyyat al-Hadis li al-Iraqiy (Madinah: al-Maktabah al-salafiyah, 1968), I: 137.

selain itu, apa yang dilakukan Motzki dengan meneliti guru abd Razzaq bukan hal yang baru dalam tradisi turas qadim yang dikenal dengan al-jarh wa al-ta'dil dan tabaqat al-rawi . 
8\%, Amr bin Dinar 7\%, Ibn Syihab az-Zuhri 6\%, Ibn Tawus 5\%, Ibn Jurayj 1\%, 103 orang 34\%, jumlah total 100\%.

c. Sufyan as-Sauri (w. 161 H) 22\%. Profil teks yang yang berasal darinya mencakup pendapat hukum as-Sauri sendiri yang lebih dominan, yakni Sufyan as-Sauri 19\%, Mansur bin al-Mu'tamir 7\%, Jabir bin Yazid 6\%, orang tanpa nama (anynamous) 3\%, 161 informan 65\%, jumlah total $100 \%$.

d. Ibn 'Uyayna 4\% sumber hadis riwayatnya adalah Amr bin Dinar 23\%, Ibn Abi Najih 9\%, yahya bin Said al-anshari 8\%, Ismail bin Abi Khalid 6\%, orang tanpa nama (anynamous) 4\%, 37 orang 50\%, jumlah total $100 \%$.

e. 90 orang $13 \%$ jumlah keseluruhan dari poin a hingga point e adalah $100 \% .^{52}$

Berdasarkan data ini Moztki menyatakan "These profile show that each source has a completeley individual face". Profil ini menunjukan bahwa keempat koleksi teks tersebut memiliki karakteristik tersendiri. ${ }^{53}$ Kekhasan masing-masing struktur mengindikasikan tidak mungkin seseorang melakukan pemalsuan (forge) dalam menyusun materi, akan membuat teks dengan perbedaan-perbedaan yang signifikan. Di samping itu, semakin detail dan mendalam penelusuran terhadap teks-teks tersebut mengenai kekhasan teks dan asal muasal sumber informasi, semakin signifkan perbedaan-perbedaan yang dijumpai.

Motzki sampai pada natijah bahwa materi-materi yang disandarkan kepada Abd ar-Razzaq kepada keempat informan utamanya adalah otentik. Gaya penyajian materi ar-Razzaq yang kerap kali mengekspresikan keraguanya atas sumber yang pasti terhadap sebuah hadis menunjukan sikapnya yang terbuka dan jujur. Hal ini menjadi ta'kid keotentikannya. Sebab, tidak mungkin seorang pemalsu akan menunjukkan sikap seperti itu yang hanya akan melemahkan riwayat yang disampaikannya. ${ }^{54}$

52 Harald Motzki, The Origins of Islamic, hlm. 59.

53 Ibid., hlm. 60.

$54 \quad$ Ibid., hlm. 60-61. 
Motzki kemudian menganalisa lebih jauh mengenai hubungan guru antara ar-Razzaq dengan perawi di atasnya yakni Ibn Jurayj. Distribusi otoritas yang tidak seimbang dan keinginan Jurayj menyampaikan pendapatnya sendiri merujuk otoritas yang lebih awal, menunjukkan bahwa ia bukan pemalsu. Hal ini didukung oleh pengujian sumber Jurayj meliputi: perbedaan isi (misal, pengunaan ra'yu didistribusikan secara tidak seimbang); perbedan pengunaan riwayat guru-murid, anak-bapak, maula-patron, perbedaan proporsi hadis dari nabi, sahabat, dan tabi'in; perbedaan penggunaan isnad dan perbedaan terminologi periwayatan (misal, penggunaan istilah 'an atau sami'tu). ${ }^{55}$

Lebih lanjut, Motzki memfokuskan dari sumber yang sering diikuti Jurayj, yakni 'Ata'. Dalam hal ini ia menggunakan teori External Criteria dan argument internal formal criteria of Authenticity yang merupakan dua alat analisa yang dihasilkan ketika Motzki meneliti penyandaran (transformasi ilmu) yang dilakukan Jurayj kepada 'Ata'. External Criteria dibagi menjadi dua, yakni pertama, Magnitude (banyak sanad dan penyebarannya). Dalam konteks ini, proporsi sumber Jurayj (lihat sub b di atas) betentangan dengan asumsi bahwa ia adalah pemalsu. Sebab ia memilih cara yang sangat complicated dengan menyandarkan materi hukumnya kepada sumber yang ia sebutkan. Jika ia pemalsu, tentunya ia akan memilih satu atau beberapa informan saja dari fuqaha' atau perawi terkenal.

Motzki menjelaskan bahwa magnitude (besarnya) distribusi transmisi Jurayj didapatkan karena ia pernah tinggal di Makkah yang memungkinkan ia bertemu dengan sejumlah sarjana, terutama ketika memasuki musim haji. ${ }^{56}$ Kedua, adalah genres (gaya atau style peyampaian). Dalam hal ini Jurayj mennjukkan otentisitas materi yang disampaikannya. ${ }^{57}$

Motzki membagi genre menjadi dua, responsa dan dicta. Yang pertama adalah jawaban atas pertanyaan, baik dari ibn Jurayj (langsung atau tidak langsung) maupun dari orang lain (dengan atau tanpa identitas). Misal, pertanyaan Jurayj: Jurayj berkata; "saya bertanya kepada 'Ata' tentang ... ia berkata...”. Sebaliknya, yang kedua dicta adalah pernyataan (qaul atau hadis)

\footnotetext{
55 Harald Motzki, "The Musannaf of ar-Razaq, hlm. 8-9.

56 Harald Motzki, The Origins of Islamic, hlm. 78.

57 Ibid.
} 
yang tidak didahului oleh pertanyaan dan bisa mengandung pendapat sendiri atau dari orang lain berupa kutipan dan deskripsi dari selain 'Ata', misalnya hadis atau atsar. ${ }^{58}$ Dilihat dari frekwensi gaya pertanyaan (direct, indirect, anonymous, and not-anonymous), menunjukkan jika Jurayj tidak melakukan projection back atau telah mengatribusikan pendapatnya kepada generasi sebelumnya. Dengan bahasa sederhana, analisis Motzki atas gaya penyajian materi 'Ata' oleh Jurayj menunjukkan implausibility asumsi bahwa ia telah melakukan pemalsuan. Sementara dilihat dari kualitas dan kuantitas responsa 'Ata' atas pertanyaan Jurayj menunjukkan keduanya terdapat korelasi historis yang panjang. 59

Motzki juga menggunakan teori argument internal formal criteria of authenticity yang menunjukkan keotentikan materi Jurayj dengan 'Ata'. Ia kemudian menginventarisir enam hal yang ia kategorikan sebagai internal formal criteria of authenticity, yakni pertama, Jurayj tidak hanya menyajikan pendapat hukum dari generasi sebelumnya, namun juga menyajikan pendapat hukumnya sendiri. Kedua, ia tidak hanya menyajikan materi dari 'Ata', melainkan juga memberikan tafsir, komentar, dan bahkan kritik terhadap materi tersebut. Motzki membayangkan tidak rasional Jurayj membuat teks sendiri, kemudian menyandarkannya secara palsu kepada 'Ata', dan pada saat bersamaan ia memberi komentar dan kritik. Ketiga, Jurayj terkadang mengekspresikan ketidakyakinannya atas maksud dan perkataan 'Ata'. Keraguan Jurayj dinilai Motzki sebagai sesuatu yang positif, yakni sebagai bukti kejujurannya dalam memproduksi ajaran dari gurunya. Keempat, terkadang Jurayj meriwayatkan materi 'Ata' dari orang lain. Kelima, ia menyajikan materi secara tepat dan verbatim. Keenam, ia terkadang menunjukan kelemahan sumber informasinya.

Berangkat dari dua External Criteria dan enam point argument internal formal criteria of Authenticity di atas, Motzki menyimpulkan; pertama, materi Ibn Jurayj dari 'Ata' yang diabadkan dalam Musannaf Abd ar-Razzaq adalah benar-benar sumber otentik. Kedua, sumber tersebut dapat dikatakan sebagai historically reliable source untuk fase perkembangan hukum di Makkah pada dekade pertama abad ke-2 $\mathrm{H}$.

\footnotetext{
$58 \quad$ Ibid.

59 Ibid., hlm. 82.
} 
Motzki melanjutkan penelitian dan analisanya mengenai sejauhmana 'Ata' menerima materinya. Menurutnya, hirarki sumber otoritas 'Ata' adalah Sahabat nabi 15\%, al-Qur'an 10\%, anynamous traditions 3\%, dan tokoh yang semasa dengannya $1,5 \%$.

Penelitian Motzki menunjukkan bahwa Ibn 'Abas adalah di antara sahabat yang sering dirujuk oleh 'Ata'. Adapun analisanya adalah: pertama, dalam responsa, rujukan 'Ata'v kepada ibn 'Abbas hanya bersifat supplementary dan Confirmative untuk mendukung pendapat 'Ata'. Artinya, rujukan 'Ata' kepada 'Abbas atau sahabat lain tidak dimaksudkan untuk memberkan "muatan otentisitas" pada pendapat hukumnya. Realita ini oleh Motzki dipahami sebagai indikasi kredibilitas 'Ata'. Kedua, secara umum, 'Ata' mengutip Ibn 'abbas secara langsung (direct references), meskipun tidak menutup kemungkinan ia mengutip secara tidak langsung (indirect references). Ketiga, dalam beberapa kasus, 'Ata' merujuk Ibn 'Abbas bukan untuk mengkonfirmasikan pendapatnya, melainkan untuk berbeda pendapat dengannya. Keempat, di samping sebagian besar riwayat 'Ata' dari Ibn 'Abbas menurut legal dicta, terdapat pula sejumlah teks yang memuat qisas. Dalam qisas ini 'Ata' mempresentasikan dirinya sebagai murid Ibn 'Abbas. Hal ini menurut Motzki "kriteria isi" tersebut menunjukkan otentisitasnya. Kelima, mengingat jumlah hadis Nabi yang allegedy diriwayatkan oleh Ibn 'Abas dalam literatur hadis yang sangat besar (sekitar 1.660 hadis), maka 'Ata' tidak mengutip dalam materi hukumnya. Dengan kata lain, materi 'Ata' dari Ibn 'Abbas yang terekam dalam Mus\}annaf, status Ibn 'Abbas bukan sebagai perawi hadis Nabi. Melainkan materi tersebut otentik dari pendapatnya Ibn 'Abbas sendiri. ${ }^{60}$

Dari kelima hal ini, Motzki berpendapat bahwa ada indikasi otentisitas riwayat 'Ata' dari Ibn 'Abas. Selain dari materi 'Ata' yang didapat dari Ibn 'Abbas, Motzki juga menganalisa dari materi 'Ata' yang lain, yakni 'Umar, abu Hurairah, Jabir dan lain-lain. Motzki melihat ada indikasi kuat kejujuran 'Ata' dalam penyebutan bsumber otoritasnya. Sampai di sini, maka Motzki berkesimpulan bahwa Musanaf karya Abd ar-Razzaq adalah dokumen hadis otentik abad pertama Hijriyah.

60 Ibid., hlm. 146-152. 


\section{Analisa Kritis atas Epistemologi Harald Motzki.}

Penggunaan Moztki terhadap teori dating (menentukan umur dan asal muasal terhadap sumber sejarah) yang di dasarkan atas sumber orisinil berupa kitab Musannaf karya Abd ar-Razzaq ditambah dengan metode isnad cum analisis dengan pendekatan traditional-historical merupakan penelitian yang dapat dipertangungjawabkan secara akademisi. Hal ini berbeda jauh dengan analisis historisnya Schacht yang didasarkan atas interpretasi terhadap fenomena semata sebagaimana tampak dalam projecting back (penyandaran ide kepada tokoh yang memiliki otoritas-nya). Meskipun demikian, jika dicermati lebih mendalam teori yang dibangun oleh Motzki sebenarnya sudah ada dalam kajian ilmu hadis dalam Islam. Misal teorinya tentang traditionalhistorical dapat disejajarkan dengan ilmu al-rijal al-hadis| dan teorinya tentang external criteria dan argument internal formal criteria of authenticity dalam periwayatan hadis dapat disejajarkan dengan teori al-tah\}ammul wa al-'ada al-hadis|.

Dalam memahami sebuah teks, menarik bila kita menelaah pemikiran Julia Kristeva, seorang pemikir post-strukturalis Perancis. Dalam kedua bukunya: Revolution in Poetic Language (Kristeva: 1974) dan Desire in Language: A Semiotic Approach to Literature and Art (Kristeva: 1979). ${ }^{61}$ Ia memperkenalkan istilah 'intertekstualitas' sebagai kunci untuk menganalisis sebuah teks. Menurutnya, relasi dalam sebuah teks tidaklah sesederhana relasi-relasi antara 'bentuk' dan 'makna' atau 'penanda' (signifier) dan 'petanda' (signified) sebagaimana dipertahankan oleh semiotika konvensional. Sebaliknya, Kristeva melihat pentingnya dimensi ruang dan waktu. Sebuah teks dibuat di dalam ruang dan waktu yang konkret. Karena itu mesti ada relasi-relasi antara satu teks dengan teks lainnya dalam suatu ruang, dan antara satu teks dengan teks sebelumnya di dalam garis waktu. Hal ini lah yang terlupakan dari kajian Motzki, di mana ia terlalu "asyik" dengan kajian teks dalam Musannaf dan jarang sekali ia melakukan interpretasi sejarah di luar teks. Pemberian porsi yang sebanding antara keduanya dengan mensintesakan secara kreatif antara teori Schacht dengan teori Motzki dapat dijadikan sebagai salah satu solusi

${ }^{61}$ Julia Kristeva, Revolution in Poetic Language (Kristeva: 1974) dan Desire in Language: A Semiotic Approach to Literature and Art (Kristeva: 1979). 
untuk mengatasi kelemahan ini, agar pemahaman terhadap teks (al-Qur'an dan hadis) tidak tercerabut dari konteks kesejarahannya. ${ }^{62}$

Bidang kajian Motzki yang hanya terbatas pada kitab Musannaf karya Abd Razzaq menjadi titik lain dari kelemahan kajiannya. Sebab, bisa saja hasil penemuan Motzki berbicara lain ketika diteliti melalui dating kitab hadis yang lain. Memang, tidak ada sebuah karya yang dihasilkan dari buah pikiran manusia yang sempurna tanpa ada kekurangan sedikitpun. Oleh karena itu penelitian yang dilakukan oleh Motzki masih terbuka bagi para peneliti yang lain, yang tentunya hal ini membawa implikasi yang positif bagi perkembangan kajian ilmu hadis. Salah satu contoh apa yang dilakukan oleh Yasin Dutton yang melakukan dating terhadap kitab al-Muwata' karya Imam Malik.

\section{E. Kesimpulan.}

Dating yang dilakukan Harald Motzki terhadap kitab Al-MusannafKarya Abdurrazzaq As-Shan'ani, dengan menggunakan metode isnad cum analisis dan pendekatan traditional-historical menunjukan bukti bahwa materi-materi yang disandarkan Abd ar-Razzaq kepada keempat informan utamanya adalah otentik. Karenanya, kitab tersebut dinilai sebagai dokumen hadis otentik abad pertama Hijriyah, sekaligus sebagai bukti nyata bahwa hukum Islam telah eksis sejak masa itu. Temuan Motzki ini sekaligus menggugurkan teori seniornya G.H.A. Juynboll J. dan projecting back-nya Schacht yang menyatakan keberadaan sistem sanad dimulai pada abad ke-2 $\mathrm{H}$.

\section{Daftar Pustaka}

'Ajjāj al-Khātib, Al-Sunnah Qablal-Tadwin (kairo: Maktabah Wahbah, 1963), hlm. 134.

'Ajjāj al-Khātib, Muhammad, Usūl al-Hadis; 'Ulūmuhu wa Mustalahuhu (Beirut: Dār al-'Ilm li al-Malayin, 1977), hlm. 231.

\footnotetext{
62 Pentingnya sejarah dalam memahami teks lihat pemikirannya Izzah Darwazah dalam Ismail K. Poonawala, "M. Izzah Darwazah's Principles of Modern Exegesis: A Contribution Toward Qur'anic Hermeneutic", dalam G.R. Haw-Ting dan Abdul Kader A. Sharef (ed.), Approach to the Qur'an (London \& New York: Routledge, 1993), hlm. 228.
} 
Abu 'Abdullah Muhammad bin Ahmad Az-Zahaby, Mizan al-I'tidal fi Naqd al-Rijal (T.tp.: Isa al-Babi al-Halaby, 1963), Juz II hlm. 609.

Abu 'Abdullah Muhammad bin Ahmad Az-Zahaby, Siyar a'lam an-Nubula' dalam CD Maktabah al-Syamilah versi III atau al-Isdar al-Salis, Juz IX hlm. 563.

Adam al-Kharasani, Mausu'ah A'lam, dalam Maktabah al-Syamilah versi III atau al-Isdar al-Salis Juz I, hlm. 286.

Ahmad Minhaji, Kontroversi Pembentukan Hukum Islam; Kontribusi Joseph Schacht (Yogyakarta: UII Press, 2001), hlm. 22.

Al-Fayyumi, Al-Misbah al-Munir fi Gharib al-Syarh al-Kabir li ar-Rafi'i (Beirut: Dar al-Kutub al-'Ilmiyyah), II: 420-421.

Ali Mustafa Ya’qub, Kritik Hadis (Jakarta: Pustaka Firdaus, 2000), hlm. 20.

Al-Sakhawi, Fath al-Mugis, Syarh al-Fiyyat al-Hadis li al-Iraqiy (Madinah: alMaktabah al-salafiyah, 1968

D.W. Hamlyn, "History of Epistemologi", dalam Paul Edwards, The Encyclopedia of Philosophy, Vol. III, 1967, hlm. 94.

E. Sumaryono, Hermeneutika, Sebuah Metode Filsafat (Yogyakarta: Kanisius, 1993), hlm. 40.

G.H.A. Juynboll, “Some Notes on Islam's First Fuqaha' Distilled from Early Hadith Literature" dalam G.H.A. Juynboll, Studies on the Origins and Use of Islamic Hadith (Great Britain: Variorum, 1996), hlm. 290-291.

G.H.A. Juynboll, Muslim Tradition; Studies in Chronology Provenance and Authorship of Early Hadith (Cambridge: Cambridge University, 1983), hlm. 98.

Harald Motzki, "The Musannaf of ar-Razaq as-San'ani a Source of Authentic Ahadith of the First Century", dalam Journal of Near Easern Studies, Vol. 50. No. 1, hlm. 1-21.

Harald Motzki, The Origins of Islamic Jurisprudence: Meccan Fiqh before the Classical Schools (Leiden: Boston Koln, 2002), hlm. 307.

Ibn Hajar al-Asqalani, Lisan al-Mizan Bab من اسمه عبد الرحيم وعبد الرزاق dalam CD Maktabah al-Syamilah versi III atau al-Isdar al-Salis, Juz II hlm. 221. 
Ibn Hajar al-Asqalani, Taqrib al-Tahzib, dalam CD Maktabah al-Syamilah versi III atau al-Isdar al-Salis, Juz I, hlm. 599.

Ignaz Goldziher, Muslim Studies (London: t.tp., 1967), II: 214.

Ismail K. Poonawala, "M. Izzah Darwazah’s Principles of Modern Exegesis: A Contribution Toward Qur'anic Hermeneutic”, dalam G.R. Haw-Ting dan Abdul Kader A. Sharef (ed.), Approach to the Qur'an (London \& New York: Routledge, 1993), hlm. 228.

Ismail. Syuhudi, Kaedah Kesahihan Sanad Hadis: Telaah Kritis dan Tinjauan dengan Pendekatan Ilmu Sejarah (Jakarta: Bulan Bintang, 1988), hlm. 113-118.

J. Sudarminta, Epistemologi Dasar: Pengantar Filsafat Pengetahuan (Yogyakarta: Kanisius, 2002), hlm. 18-21.

Joseph Schacht, An Introduction to Islamic Law (Oxford: Clarendon Press, 1990), hlm. 11.

Joseph Schacht, The Origins of Muhammadan Jurisprudence (Oxford: Ciarenoon Press, 1950), hlm. 40.

Julia Kristeva, Revolution in Poetic Language (Kristeva: 1974) dan Desire in Language: A Semiotic Approach to Literature and Art (Kristeva: 1979).

Kamaruddin Amin, "Book Review The Origins of Islamic Jurisprudence Meccan Fiqh before the Classical School”, dalam Al-Jamiah: Journal of Islamic Studies (Yogyakarta: UIN Sunan Kalijaga Yogyakarta, 2003, No. 1, Vol. 41), hlm. 2.

Kamaruddin Amin, The Reliability of Hadith Transmission, A Reexamination of Hadith Critical Methods, Bonn 2005).

M. Alfatih Suryadilaga, "Model-model Living Hadis", dalam Sahiron Syamsuddin (ed.), Metodologi Penelitian Living Qur'an dan Hadis (Yogyakarta: Th-Perss dan TERAS, 2007), hlm. 105.

M.Arkaoun, Rethingking Islam, terj. Yudian W. Yasmin dan Lathiful Khuluq (Yogyakarta: Pustaka Pelajar, 1996), hlm. 73.

Ma'mar bin Rasyid al-Azdiy, Faharis al-Musannaf 'Abd al-Razaq (Beirut: alMaktab al-Islamiy, t.t.), hlm. 1. 
Muhammad 'Ajjaj al-Khatib, Al-Sunnah Qabl al-Tadwin (Beirut: Dar al-Fikr, 1981), hlm. 92-93.

Muhammad 'Ajjaj al-Khatib, Ushul al-Hadis; 'Ulumuhu wa Mushthalahuhu (Beirut: Dar al-'Ilmu li al-Malayin, 1977), hlm, 32.

Muhammad bin Ja'far al-Kattani, Ar-Risalah al-Mustafat (Beirut: Dar al-Ilmi, 1322), hlm. 31.

Muhammad Hakim al-Naisabury, Ma'rifat Ulum al-H\}adis|; Kairo: Maktabah al-Mutanaby, t.t, hlm. 53;

Muhammad Ibn Sa'ad, at-Tabaqat al-Kubra (Leiden: E.J.Brill, 1322 H.), Juz V hlm. 548.

Muhammad Mustafa Azami, Hadis Nabawi dan Sejarah Kodifikasinya, terj. Ali Mustafa Yaqub (Jakarta: Pustaka Firdaus, 2004), hlm. 531-534.

Muhammad Mustafa Azami, Menguji Keaslian Hadis-hadis Hukum (Jakarta: Pustaka Firdaus, 2004), hlm. 232.

Muhammad Mustafa Azami, Studies in Hadith Methodology and Literatur, edisi Indonesia terj. A. yamin Metodologi Kritik Hadis, terj. A. Yamin (Jakarta: Pustaka Hidayah, 1992), hlm. 61.

Muslim bin al-Hajjaj, Shahih Muslim bi Syarh al-Nawawi (Beirut: Dar alKutub al-Ilmiah, 2003), I: 78. Lihat juga

Nasr Hamid Abu Zayd, Mafhum al-Nash: Dirasah fi Ulum al-Qur'an (Beirut: al-Markaz al-Tsaqafi al-'Arabi, 2000).

Nasr Hamid Abu Zayd, Rethingking the Qur'an: Toward a Humanistic Hermeneutics (Amsterdam: Humanistic University Press, 2004), hlm. 9-12.

Nuruddin al-Itr, Ulumul Hadis, terj. Endang Soetari dan Mujio (Bandung: Rosdakarya, 1992), hlm. 181.

Sumardi Suryabrata, Metodologi Penelitian (Jakarta: Rajagrafindo Persada, t.t), hlm. 81-82.

Syamsuddin 'Arif, "Gugatan Orientalis terhadap Hadis dan Gaungnya di Dunia Islam”, dalam Jurnal al-Insan, Jakarta, No. 2, Vol. I, 2005, hlm. 15. 
Syaukat Jamilah, "Pengklasifikasian Literatur Hadis", dalam Al-Hikmah, No. 13 April-Juni 1994, hlm. 24-26.

Syuhudi Ismail, Kaedah Kesahihan Sanad Hadis: Telaah Kritis dan Tinjauan dengan Pendekatan Ilmu Sejarah (Jakarta: Bulan Bintang, 1988), hlm. 75-104.

Syuhudi Ismail, Metodologi penelitian Hadis Nabi (Jakarta: Bulan Bintang, 1992), hlm. 67.

Titus dkk., Persoalan-persoalan Filsafat, terj. Rasyidi (Jakarta: Bulan Bintang, 1984), hlm. 20-21. lihat juga

Yusuf bin az-Zaki al-Mizzi, Tahzib al-Kamal dalam CD Maktabah al-Syamilah versi III atau al-Isdar al-Salis, Juz IV, hlm. 47. 